\title{
Ciała pozbawiane powierzchni. Imago
}

Obydwa oddalone tu od siebie rysunki Schulza (ten z pierwszej strony zeszytu i z czwartej strony okładki) stanowią w rzeczywistości materialną jedność. Fizycznie nie da się ich rozdzielić, ani nawet równocześnie zobaczyć. To awers i rewers tej samej kartki. Separacja była możliwa dzięki reprodukcji i przeniesieniu rysunków na inne płaszczyzny. Sposób ich umieszczenia w „Schulz/Forum” powtarza jednak to pierwotne usytuowanie i wymusza na oglądającym działanie polegające na prostym odwróceniu kartki. Podobnie było podczas rysowania, które w latach trzydziestych staje się dla Schulza bardziej akcją niż kreacją - zdarzeniem, działaniem performatywnym pozostawiającym w jego rysunkach ślady raz bardziej, raz mniej czytelne.

Nie można jednak w tym wypadku z całą pewnością rozstrzygnąć, co Schulz najpierw narysował: szkic ekspresjonistycznie rozedrgany, który mógłby być projektem scenografii do filmu Gabinet doktora Caligari Roberta Wienego, czy plątaninę kresek (przypominającą szkice Giacomettiego), w której z trudem da się rozpoznać ciała bałwochwalców adorujących siedzącą na krześle kobietę. Ustalenie kolejności nie ma zresztą większego znaczenia. Ważne, że obydwa rysunki pokazują dwa stopnie, dwie fazy rozpadu form. W nurcie tego samego procesu ciała tracą swoją integralność. Przedstawione zostały przez Schulza jako seria skokowych wyglądów, między którymi nie ma więzi, więc także ciągłości. Jedynie twarz adorowanej kobiety zachowuje swą tożsamość. Twarze adorantów na rysunku $\mathrm{z}$ okładki zredukowane do prostego schematu (oko to kropka, nos kreska pionowa, usta - pozioma), na rysunku inicjalnym zeszytu rozpadają się tak samo jak ich ciała. Ale ciało kobiety o wyraźniej określonej twarzy także już jest w stanie daleko posuniętej destrukcji. I jej ,jakże pełna uroku i jak szczęśliwa forma bytu" ulegnie w końcu rozpadowi, choć tego jeszcze tu nie widzimy.

Przywołane rysunki pochodzą z lat trzydziestych. Początki rysownika nie zapowiadały tak wielkiej katastrofy cielesnych form. W pracach drugiej i częściowo trzeciej dekady XX wieku Schulz precyzyjnie i jednoznacznie definiuje ludzkie figury. Teraz jednak dumne pozy, które przybierał rysując siebie (przykładem narcystyczny autoportret lwowski) i w których ujmował rysowane przez siebie postacie (Budracką czy Weingartena), są już chyba niemożliwe do powtórzenia. W ostatniej dekadzie życia (i twórczości) Schulz rysuje inaczej, bo chyba też inaczej patrzy na siebie i innych. Ciało? To dla rysownika pęki wibrujących linii. Autoportret? Możliwy jako psychologiczne studium, karykaturalnie wyolbrzymiające cechy indywidualne, lub ikona siebie samego (duża głowa, na niej zwykle kapelusz, niewielki wzrost). W setkach kompulsywnych szkiców z lat trzydziestych 
nawet te zasady przestają obowiązywać. Rysowane przez Schulza ciała - nieważne własne czy cudze - dochodzą nieraz do granicy, za którą jest już tylko drżenie. Ruch i przemieszczenie. Szkice Schulza nie poszukują formy. Są świadectwami jej rozbicia czy może lepiej - rozedrgania, rozwiązania, rozproszenia.

Dla oka ciało jest fenomenem powierzchni. Dopiero redukcja dystansu w akcie miłosnym (lub akcie agresji), a nawet dotknięcie czy zwykły uścisk dłoni zmieniają ten stan. Być może zatem problem przedstawiania przez Schulza ciała sprowadza się do patrzenia. Ciało narysowane nie ma zapachu ani ciężaru (ani też smaku - nie jest „mięsne”). Nie można go nawet dotknąć. Ręka wyciągnięta w kierunku nagich kobiet, które przybierają na rysunkach Schulza pozy władcze i prowokacyjne, napotka jedynie kartkę papieru. Ciało narysowane istnieje tylko dla oka. Zachowanie powierzchni jest więc dla tak istniejącego ciała ostatnią szansą na ocalenie. Dlaczego więc ciała z późnych rysunków Schulza tracą integralność, dlaczego tak często rozpadają się - w oczach? Czym dla Schulza-rysownika i Schulza-pisarza jest ciało? Jak doświadcza on własnej cielesności? Jak siebie widzi? Jak widzą go inni?

Pisanie wstępu do „Schulz/Forum” nie jest łatwym zadaniem. Nie zakłada żadnych reguł prócz rygoru objętości, ale to ograniczenie działa jak gilotyna. Sprawdzam z niepokojem statystykę znaków. Żal mi, że muszę zawiesić rozważania na temat imago zeszytu, który obrał sobie jako lemmę ciało u Schulza (i Schulza) i rozwija ją w kolejnych subskrypcjach. Żal mi, że te subskrypcje zapowie jedynie spis treści - bez słowa komentarza. Jedyny wyjątek to kilka zdań o nagłym i niespodziewanym pojawieniu się w tym zeszycie Georga Groddecka.

Listy tego ekscentrycznego psychoanalityka, tworzące osobliwą powieść epistolarną Das Buch vom Es (wydaną w 1923), przypominają tyrady Jakuba na temat wtórej demiurgii, którymi uwodził Paulinę i Poldę. Ale też przywodzą na myśl praktyki samego Schulza piszącego listy do Debory Vogel, do Romany Halpern, do Anny Płockier. W tego rodzaju strategii słowo jest wszystkim - pozwala ukryć ciało biologiczne i stworzyć symboliczne. Ale Groddeck - o cielesności stabilnej i ekspansywnej (vide załączone fotografie) - ujmuje ciało w szczególny sposób. Nie jest ono według niego bytem obdarzonym duszą, lecz wytworem tajemnej siły, która zawiązuje się w momencie poczęcia, gdy „plemnik łączy się z jajem”. Odtąd już wszystko (i ciało, i umysł) jest wytworem Es - czyli O n o. I ono nami żyje.

W czasach, gdy Groddeck pisze i publikuje Das Buch vom Es - Książkę Ono, Schulz pracuje nad własną książką - a nawet nad Księgą, nad Xięgą bałwochwalcza. Forma cielesna (jako gest i poza) zachowuje w niej jeszcze integralność, jeszcze możliwy jest zatem opis (prezentacja) przygód ciała, choćby daleko wykraczały one poza obyczajową normę. Wkrótce jednak te występki i ekscesy cielesne stracą swoją siłę. Schulz dojdzie do punktu, w którym ciało, rozpadając się na serię osobnych wyglądów, zostanie pozbawione powierzchni.

Jak więc wyjaśnić serię lukrowanych portretów pewnej nauczycielki z Drohobycza, które są ostatnią subskrypcją? Jaki jest sens tej recydywy? sr 